\title{
The Tokyo Medical University entrance exam scandal: lessons learned
}

\author{
Greg Wheeler(D)
}

Correspondence:

wheeler@sapmed.ac.jp

Sapporo Medical University, South

1, West 17, Chuo-ku, Sapporo

060-8556, Japan

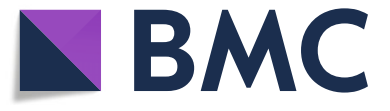

\begin{abstract}
The recent scandal involving Tokyo Medical University's practice of restricting the number of incoming students, primarily female, by systematically lowering their entrance exam scores has once again shone a spotlight on the issue of gender discrimination in Japan. The bulk of the media coverage to date has centered on the manner in which the female applicants to the university have been treated unfairly and how societal perceptions of women's roles in the workplace may be in need of significant revision. In the present paper, the author will provide an overview of this aspect of the situation and suggest potential means to be taken by the university to redress its actions. Additionally, the author will examine another extremely important aspect of the scandal, namely, how the university was able to conduct its discriminatory practice unchecked for over a decade, a topic that has received less attention. Possible means through which similar scandals may be avoided in the future will also be discussed.
\end{abstract}

Keywords: Gender discrimination, Hensachi, Entrance examinations, Score manipulation, Societal expectations

\section{Introduction}

When stating their overall mission or objectives, Japanese medical universities frequently emphasize their dedication to ethics and morality. The School of Medicine at Hokkaido University submits, "the mission of the School of Medicine is to help undergraduates develop the professional ethics and well-rounded characters required for medical professionals" (Hokkaido University 2017). Appearing in Sapporo Medical University's code of conduct are statements declaring, "We will abide by law and respect bioethics, research ethics and social ethics" and "respect human rights, personalities and individuality and create an environment free from discrimination and harassment" (Sapporo Medical University n.d.). The Faculty of Medicine at Kyoto University aims to instill in its students "a broad understanding of society and human behavior" and "good morals" (Kyoto University n.d.). Likewise, Tokyo Medical University (hereafter, "TMU") stresses the importance of instilling a moral code among its students, declaring that those obtaining a degree at the school have acquired "the practical skills and ethical outlook required of a doctor" (Tokyo Medical University n.d.a).

It is the final university among those listed above that presently finds itself embroiled in a major scandal due to its decidedly unethical conduct concerning the manner in which it had been marking its entrance examinations. As has been widely reported in

(c) The Author(s). 2018 Open Access This article is distributed under the terms of the Creative Commons Attribution 4.0 International License (http://creativecommons.org/licenses/by/4.0/), which permits unrestricted use, distribution, and reproduction in any medium, provided you give appropriate credit to the original author(s) and the source, provide a link to the Creative Commons license, and indicate if changes were made. 
Japan and abroad, an investigation into TMU's methods for determining admission found that it had been for years manipulating the exam scores of its female applicants in order to curb the number of women successfully entering the university (Asahi Shimbun 2018a; BBC News 2018; McCurry 2018; Murakoshi and Sano 2018; Nihon Keizai Shimbun 2018a; Tanaka and Izutani 2018; The Japan Times 2018a; Tokyo Shimbun 2018). Additionally, it was discovered that scores for male applicants who had previously taken the exam three times (unsuccessfully) had been lowered as well (Nikkan Sports 2018). Conversely, it was determined that scores for numerous applicants whose families had made donations to the university were significantly raised (The Mainichi 2018). Although early reports indicated that this practice likely began after the 2010 examination period, it is now understood that it had in fact been occurring for over a decade before finally being discovered (BBC News 2018; Nogi 2018).

Although it has not just been female applicants affected by TMU's score-lowering scheme, it is the ugly specter of gender discrimination, a practice commonly considered to be rampant in Japanese society, which has caused the greatest uproar. Since its practice was discovered, TMU has been rebuked often and severely for its actions.

Although the outrage over the gender discrimination policy has understandably received substantial media scrutiny, there has in contrast been less mention concerning how TMU and possibly other universities were able to continue this practice undiscovered for such a considerable duration. It was, in fact, only by chance that the present issue came to light, unearthed during an investigation of a separate incident at the university (McCurry 2018). This aspect of the scandal needs to be scrutinized more thoroughly in order to determine means to prevent it from occurring again. As such, a major focus of the present paper is to examine the environment surrounding the application system currently in place among Japanese universities and how this may have enabled TMU to conduct its discriminatory policy unchecked. Additionally, possible means to prevent such ethical breaches from occurring in the future will be discussed toward the conclusion of the paper.

\section{Fierce competition for admission to Japanese medical schools}

One reason for the uproar over the present scandal is at least partially due to the competitive nature inherent in the admission process to Japanese medical universities. At present, the medical schools are generally considered to be among the most prestigious and selective of all university programs in Japan. They have seen a surge in applicants over the past decade, with many of the top-ranked high schools in the country steering their students toward applying to medical programs. As such, even with all applicants being treated in an equal manner, gaining admission is already often notoriously difficult.

Indicative of their status, most of the medical schools are assigned hensachi scores far above the national average. The hensachi is a standard deviation score, indicating how far from the mean a student who is admitted to an institution (usually a college or university but also can include secondary and even primary schools) has scored on a test (Makino 2016). A score of 50 is considered the mean, while that of 60 is one standard deviation above the mean. Any score above 65 is considered an extremely high hensachi. A Japanese university's hensachi score, which is often assigned by the juku, private schools that help prepare students for the rigors of the entrance exams, is 
enormously important because it the most commonly recognized manner in which its ranking is determined. These scores may vary by individual departments and schools within the universities, but the hensachi of most medical programs in Japan is above 65 (Igakubu Juken Manual n.d.; Kawaii Juku Ishin Juku 2018a; 2018b). With a seemingly ever-increasing number of high school students hoping to attend the highly ranked medical schools, admission to these programs has likewise invariably become more competitive. According to a recent survey administered by the Japanese Ministry of Education, for example, in 2017 only $6.6 \%$ of male applicants successfully gained admittance to medical school programs (Murakoshi and Sano 2018). For women, the success rate was even lower at 5.9\% (Murakoshi and Sano 2018).

\section{Tokyo Medical University application process}

The hensachi score for TMU generally ranges between 66.5 and 67.5, which places the university toward the middle of the overall ranking of medical programs (Igakubu Juken Manual n.d.; Kawaii Juku Ishin Juku 2018b). The university is a private school with approximately 120 new students enrolling annually. Although some applicants are able to gain admission to the university via a recommendation from their high school principal (in Japan, most medical programs are 6 years and students may enroll in them upon graduation from high school), the majority (recruitment goal of 93) vies for acceptance through ippan nyügaku (general admission), which involves two stages (Tokyo Medical University n.d.b). Most of those attempting to gain admission through ippan nyügaku first take the university's entrance exam. Those that receive a sufficiently high score on this exam are then allowed to proceed to the second admissions stage, which includes having them submit a short essay and sit for an interview. Seventy-five openings are accorded through this two-stage process and it is here in which the alterations to exam scores occurred. (An alternative means of ippan nyügaku consists of applicants taking the National Center Test in January, followed by the university's entrance exam, but fewer enter the university via this route.)

As can be observed on the section of its website providing information to potential applicants (Tokyo Medical University n.d.c), TMU is similar to most medical programs in Japan in that there are a great number of applicants competing for the few available openings. For example, among the 75 spots available through ippan nyügaku in 2018, there were initially 2935 candidates expressing interest (Male, 1811; Female, 1224), with 2614 eventually sitting for the examination (M, 1596; F, 1018). Of these, only 451 (M, 303; F, 148) were determined to be eligible to continue to the subsequent essay and interview stage. One hundred seventy-one (M, 141; F, 30) applicants successfully passed this second stage; ultimately, 71 male students and 14 female students enrolled. (Although the university's stated recruitment goal for the main ippan nyügaku is 75 , it is not a figure seemingly set in stone.) Eight other applicants achieved admittance through the alternative ippan nyuggaku route, and an additional 27 were able to enroll through the high school recommendations, for a total of 120 first-year students.

\section{Manipulating the exam scores}

After the 2006 examination period, officials at TMU were reportedly concerned at the number of women successfully attaining admission to the university. According to an 
(unnamed at present) official at the university, this concern centered on a belief that the longevity of medical careers for female physicians tended to be insufficiently short (The Japan Times 2018a; Tokyo Shimbun 2018). It was felt that female medical students did not plan to practice medicine long-term and upon getting married and having children were likely to take lengthy maternal leaves or even depart the profession. TMU officials feared this in turn would adversely affect its affiliated hospital. It is common for students upon graduation to begin their professional careers at the hospital of the school from which they graduated. Officials at TMU apparently felt that since female graduates generally practice for only a comparatively short time before leaving the profession, their early departure would cause a shortage of physicians at its hospital, thereby increasing the workload and pressure for the remaining physicians. By this logic, it was determined to be imperative to restrict the number of female applicants entering the university. The university additionally took measures to curb the acceptance rate of applicants who had failed the examination at least three times previously. Although there has been less discussion regarding this, it may perhaps be surmised that administration concluded that if these applicants - known as ronin were unable to obtain acceptance during their previous attempts, they did not meet the expected standards of the university and were therefore unworthy of acceptance.

To curb the number of successful female (and rōnin) applicants, the university adopted a scheme in which it lowered their actual entrance examination scores by as much as $20 \%$ (The Japan Times 2018a). This proved to be an effective means of reducing the number of women receiving scores deemed high enough to proceed to the second stage of the application process. On the 2018 examination, for example, 18.9\% of the male applicants passed this first stage, considerably higher than the $14.5 \%$ of the female applicants who passed after having their scores lowered (Nihon Keizai Shimbun 2018a).

It is this first stage of the application process that has received the most attention. However, it should also be noted that the second phase - the short essay and interview - resulted in even more precipitous drops in the number of successful female applicants. Of the 303 male applicants who passed the first stage of the 2018 exam, 141 also passed the second stage, resulting in an overall acceptance rate of 8.8\% (Tokyo Medical University n.d.c). In contrast, only 30 of the 148 female applicants, just $2.9 \%$ of those who sat for the examination, who passed the first stage succeeded in passing the second stage (Tokyo Medical University n.d.c). To date, there have been no official reports about what transpired during the interviews at TMU. However, there have been testimonies from female applicants at other medical programs about having to endure questions during their interviews that focused less on their abilities and more on their future marriage plans or desire to have children (Tanaka and Kinkozan 2018). Even if verified reports of these types of questions being asked during the interviews at TMU have not appeared, that nearly $47 \%$ of the male applicants who passed the first stage also passed the second compared to just over $20 \%$ of the female applicants achieving similar success suggests a strong gender bias.

The discrepancy in the acceptance rate for male and female applicants perhaps reached its peak during the 2018 application process. However, since the 2010 exam, the rates of male applicants successfully attaining admission (ranging between 4.8 and $8.8 \%$ ) have always been higher than those of their female counterparts (2.9 to 6.4\%) (Tokyo Shimbun 2018). Interestingly, despite the attempts to limit the number of 
successful female applicants, women still made up 45\% of the 2017 incoming class (New's Vision 2018), well above the average percentage of female students attending medical programs in Japan (Igaku Juken Labo 2018). Without the exam score manipulation, it is not unreasonable to believe that women would have comprised over half the student population of the class.

\section{Reflection of societal values?}

Gender equality in the workplace has been an issue in which Japan has long been criticized. Employers are routinely accused of expecting and even pressuring their female employees to step down from their positions once they marry or have children. Although women make up more than $40 \%$ of the total workforce in Japan, they continue to be underrepresented in fields such as medicine (McCurry 2018). It is perhaps not surprising that the World Economic Forum in 2017 ranked Japan 114th out of 144 countries concerning matters of gender equality (World Economic Forum 2017).

This trend seems to be especially prominent in Japan's medical profession, with female doctors comprise approximately $21 \%$ of the total number of physicians in Japan, under half the OECD average of 45\% (McCurry 2018). This is particularly troubling because the country is already suffering from a shortage of physicians. According to the Organization for Economic Cooperation and Development (OECD), Japan's rate of 2.4 doctors per 1000 inhabitants is lower than all but four of the industrialized countries (Organization for Economic Cooperation and Development (OECD) 2018).

Unfortunately, this situation presents officials at universities such as TMU with an opportunity to defend their policies. Since there are so few female doctors and those that do practice medicine are believed likely to leave the profession early, they can justify their score-lowering practice, arguing that it makes sense to protect the hospital from having too few physicians by ensuring that the majority of them are male, who are more likely to continue their practice for a longer duration.

Moreover, the results of a survey conducted among female physicians in Japan by a medical recruiting company soon after the TMU scandal broke further enforces this manner of thinking and highlights the struggles many women feel they face in the medical profession (Asahi Shimbun 2018b; NHK World - Japan 2018). When asked about their reaction to TMU's practice of lowering the exam scores of female applicants, $65 \%$ of the participants replied they could understand the reasoning behind the university's decision to change the scores. They did not express approval of these alterations, but acknowledged that women leaving the profession after childbirth could increase the workload for the remaining doctors. Several noted, however, that the system presently in place for pregnant women or new mothers was unsatisfactory, likely making it difficult for those women to continue working. Many others also recounted experiences of discriminatory treatment in the workplace.

Although TMU has been subject to the majority of criticism, it has become increasingly evident that it is not alone among medical universities engaged in exam score manipulation. As noted earlier, according to a Ministry of Education report, only 5.9\% of women who applied to medical programs in 2017 were accepted, whereas the rate was $6.6 \%$ for male applicants. Although this difference may initially appear inconsequential, it becomes more pronounced upon examining the acceptance rates for other 
competitive fields. For example, among the science disciplines, the acceptance rate for male and female applicants was equal (11.6\%) and in the engineering field, the acceptance rate for women was $12.2 \%$, slightly higher than that of men (Murakoshi and Sano 2018). These percentages suggest that TMU is not in fact the only medical school attempting to curb the number of female applicants successfully gaining admission (Tanaka and Kinkozan 2018) and shortly after the university's misconduct regarding the exam scores was discovered, the Ministry of Education ordered an investigation of all medical programs in Japan regarding the possibilities of gender discrimination. Although the investigation is ongoing, preliminary results of this probe indicate that a number of other medical universities have been engaging in practice similar to that of TMU (Kyodo News 2018). The Ministry has not named these schools, determining that more conclusive evidence is necessary and at present, none has admitted to lowering the scores of female applicants. There have been reports that female applicants to the medical school at Juntendo University may have been discriminated against, but a university official has denied that such conduct has occurred (Mainichi Shimbun 2018). Additionally, the medical school at Showa University has recently admitted that it increased the scores of applicants taking its exam for the first or second time and also showed preferable treatment to applicants whose family members were alumni of the university (Sankei News 2018). It has, however, denied that its discrimination was in any way gender based. Of note, although the Ministry of Education has condemned TMU's actions and initiated a review of the entrance process for all medical programs in Japan, it does not officially oppose the concept of gender quotas. It merely requires that programs make their policies concerning this clear (Murakoshi and Sano 2018). Its rebuke of TMU is seemingly due to the university's attempt to keep its gender quota secret.

\section{Financial considerations}

Although much of the scrutiny of TMU has focused on the social aspect of treatment of women in Japan, the university's actions have also affected applicants and perhaps even present students financially. Applying to Japanese universities can be an expensive venture and this is particularly true for private medical schools. At TMU, the entrance examination fee for those applying through the main ippan $n y \bar{u} g a k u$ process is 60,000 yen (approximately 540 US dollars) (Tokyo Medical University n.d.b). Moreover, considering how few openings there are for candidates, many - if not the majority of - potential students may attend juku, hoping to gain some manner of competitive edge that will bolster their chances for admittance. These $j u k u$, especially those focusing on medical school entrance exams, are often extremely expensive. Fees for 1 year at some of these schools may exceed considerably more than 2,000,000 yen (Medic Tomas 2017; Medical Labo n.d.). Considering that many students wishing to attend a medical program may begin studying at juku from their first year of junior high, it can clearly be a costly investment. Moreover, there is a limit to the number of universities to which students can apply every year, resulting in many of those unsuccessful in their initial attempt to enter a medical program becoming rōnin, spending the entire subsequent year studying, often at the expensive preparatory schools, for next year's exam. 
Applicants possibly incurring these enormous expenses before or after being denied entrance at TMU because officials lowered their scores may be understandably demoralized.

Moreover, female students actually accepted at the university despite having their exam scores lowered may also be affected financially. Private universities, and especially the medical schools, incur considerable expenses. Students entering TMU in 2018, for example, were required to pay 7,400,000 yen in enrollment and various tuition fees (Tokyo Medical University n.d.d). These included a one-time enrollment charge (100,000 yen), basic tuition (2,500,000 yen), training fees (400,000 yen), facility and equipment costs (1000,000 yen) and various additional educational expenses $(2,500,000$ yen). Other miscellaneous expenses amounted to 178,700 yen, for a total of $7,578,700$ yen (approximately 68,000 US dollars) students had to pay their first year. Considering these costs, entering the university can be considered a daunting financial prospect for many students.

However, for those newly enrolled students whose entrance exam scores were in the top 35 among the entering class, the university waived the first-year basic tuition and additional educational fees, resulting in their tuition costs being reduced by 5,000,000 yen (Tokyo Medical University n.d.d). This is a significant reduction in expenses, but one likely to be exceedingly difficult to attain for those female applicants whose scores were lowered by up to $20 \%$.

\section{Recommended actions to be taken by TMU}

It is an understatement that TMU's reputation has been shattered since news of its exam manipulation policy was made public. The challenge now facing it is to find a way to regain the public's trust in its admissions procedures. Reimbursing the 60,000 yen application fee to all those whose exams scores were lowered would be a reasonable - if minimal - first step toward demonstrating contrition. An even stronger expression would be to determine the number of applicants who scored high enough on stage one of the entrance process and retroactively offer them admission or at least the opportunity to bypass the exam and directly proceed to the second stage during the following year's application process.

TMU has, in fact, recently announced its plans to accept students discriminated against, albeit to a limited extent. It has declared that it will offer admission to applicants rejected due to the score manipulation on the 2017 and 2018 exams (Japan Today 2018). This is undoubtedly a welcome step, but also raises new questions. If, for example, any of the initially rejected applicants are presently attending other schools but decide to enroll at TMU, will the university reimburse them their tuition fees at the other universities? Moreover, what recourse is available to those denied admission prior to the 2017 exam? Also, since similar to most medical programs in Japan, TMU places a cap on how many applicants it accepts every year, will offering retroactive admission to those rejected in 2017 and 2018 result in a reduction of new applicants offered admission in 2019? Overall, the decision to accept the applicants from the 2017 and 2018 exams is a positive measure from TMU, but has little to no effect on those discriminated against in 2016 or earlier. As such, at the very least those applicants should be reimbursed the exam fee. 
TMU has also recently announced plans to lower the overall costs for students during their 6 years at the university. At present, during their 6 years at TMU, it is estimated that students will pay 29,800,000 yen (Livedoor News 2018). TMU has declared that this figure will be lowered by 10,000,000 starting from 2020 (Livedoor News 2018). Again, however, although this is an encouraging development, it is not one that directly affects those denied admission prior to 2017 or even those who were able to gain entrance but have since graduated or will do so in the next couple of years. It also does not address the issue of possible compensation for successful enrolling applicants who may have had overall scores within the top 35 ranking before the adjustments to the exams. These students, if any, would have been eligible for the 5,000,000 yen reduction in fees during their first year. Although it is probably unrealistic to expect the university to reimburse each of these students an amount equivalent to this reduction (depending on the number of students affected, the costs could be staggeringly high), providing some means of additional financial support for these students would be a welcome step.

\section{Entrance exam system enabling TMU and other schools?}

The creation, content and marking of university entrance exams is extremely secretive and universities take numerous precautions to ensure that exam material does not leak to the public or anyone not directly related to the creation of the exam before the tests are held.

This adherence to secrecy occasionally results in problematic situations. Those who create these exams are not infallible; there have recently been several widely publicized incidents involving errors on the exams. On the physics section of Kyoto University's 2017 exam, for example, a question appeared that was later found to have no possible answer (The Japan Times 2018b). Four thousand four hundred twenty-nine applicants took this exam and upon discovery of the error, all were given full credit for their answers to this question. This resulted in 17 applicants initially rejected from admittance subsequently being allowed to enroll, and another 11 who had gained admittance were able to transfer to their first-choice faculty. The previous year, Osaka University also allowed an additional 30 applicants to enroll after errors were discovered among the physics questions on its entrance exam (The Japan Times 2018b). Additionally, an error on the 2018 Sapporo Medical University exam necessitated all applicants' scores to be readjusted, resulting in an additional examinee being admitted (Asahi Shimbun 2018c).

Unlike the situation at TMU, of course, these errors were accidental. Perhaps of greater importance, they may have been discovered only because the access restrictions to the test problems are somewhat eased once the examination period ends. Universities, for example, wishing to remain in favor with the $j u k u$, may provide them with a copy of the exam. Alternatively, because examinees are allowed to keep the test questions, a juku representative may purchase a copy from test takers. Soon after, often as quickly as the following day, many of these exam problems will appear on the websites of the juku. As such, if there are errors on the exams, they will likely be quickly discovered and universities whose tests contained mistakes will immediately try to rectify the situation. However, if there are no obvious mistakes present among the exam content, such has seemingly been the case with those from TMU, no such action by the universities is necessary. 
Moreover, even with the exam content becoming more publically available upon the completion of the test period, most universities remain reluctant about dispersing much information about the tests and especially the scoring of them. They rarely post exam contents on their websites, nor do they make public what are considered the correct answers to the exam problems. Additionally, universities do not routinely send exam results to the applicants. Applicants learn of their outcome shortly after the exam period ends, when the universities post lists of the (seating) numbers of the successful applicants on their websites or campus bulletin boards. Those not accepted are almost never provided with information concerning their examination score or how close they were to the cutoff for acceptance. The process is based on a public faith that the universities are being honest regarding the manner in which the examinations are scored. With almost no accountability, it should not be surprising that TMU was able to alter the scores without discovery for such an extended period.

\section{Changes needed to avoid future incidents}

Results of the Ministry of Education's probe, indicating that TMU was just one of numerous universities engaged in gender discrimination, are indicative of the challenges often facing women hoping to enter the medical profession. Moreover, they appear to be well aware of this situation. Results of a recent study surveying the work-life balance of female physicians indicate that female medical students seem resigned to the expectation that regardless of their situation in the workplace, housework and childcare are primarily their responsibility (Takahashi et al. 2017). The survey, participated on by first- and sixth-year female and male medical students, included questions about their views of the manner in which female and male physicians are treated at work and factors that might influence female doctors' decisions to continue working in or leave the medical profession. Results indicated a belief that treatment would likely vary depending on the department in which one worked, but overall only a low percentage of the female students, especially those in their first year, believed male and female physicians received equal treatment (Takahashi et al. 2017). Additionally, concerning circumstances affecting their medical career longevity, results of the study indicated that the female students believed that pregnancy and childbirth would be factors strongly influencing their decision to leave the workplace (Takahashi et al. 2017). These factors - the belief that they will not be treated as equals to their male co-workers and the assumption that their time in the workplace depends on their marital and/or child-rearing status - are strong deterrents from entering the world of medicine. Unless steps are taken to make it more feasible for women to remain in the medical profession for a longer time period, university officials may continue to justify their discriminatory practices.

In a sign that women are fighting back against the discrimination, in late October many of the female applicants denied entrance to TMU brought a suit against the university, demanding compensation (Nogi 2018). Among their demands, they requested the university pay 100,000 yen to each applicant as payment for mental anguish endured and demanded that the university show test score results.

That latter demand by the group is of considerable importance. Concerning the admission process, greater transparency is needed in order to prevent these scandals 
from occurring regularly. The Ministry of Education seems to recognize this and addressed the situation even before the present scandal came to light. In June of this year, it sent a directive that emphasized the importance of more openness regarding the exams to all the boards of education, university presidents and other organizations throughout the country with ties to the university admissions process (Ministry of Education, Culture, Sports, Science and Technology (MEXT) 2018). Among its suggestions, the Ministry strongly recommended that universities, upon completion of the admissions period, make both the contents of their exams and correct answers to the problems publically available. It did acknowledge that some of the answers might be subjective, especially those that required examinees to write paragraphs or short essays, meaning that there would likely be no single correct answer for those problems. In such cases, the Ministry recommended that the universities at least explain the purpose of the problems, and provide a general or standard idea of the content expected among the answers.

This is an encouraging step, but one not without limits. The contents of many of the exams, especially the English or Japanese sections, include passages that are made up of already published material. Although Article 36 of the Japan Copyright Law allows for such material to be included on the exams, this provision does not likely allow for it to appear on the university websites (Copyright Research and Information Center n.d.). Therefore, universities would either have to receive consent from and provide remuneration to the original copyright holders or omit those sections when putting the exams on their websites, the latter of which would likely render the exam answers meaningless due to a lack of context.

Moreover, there may be reluctance among universities to make "official" answers to paragraphs or short essays public because of their subjectivity. Making them readily available to the public, or even merely including the problems' intent, could invite scrutiny and potential arguments that there are many other interpretations of the questions that, although differing from the answers appearing on the universities' websites, should be considered acceptable. The $j u k u$ in particular pore over these exams and provide sample answers to their students. They also issue public evaluations of the exams' merits. The juku considerably influence public perceptions of the universities. If they conclude that the sample answers or information posted by a university is insufficient or even incorrect, they may assign a low rating to the exam, which in turn can negatively affect the university's hensachi score. This is a situation that universities, many of which are already struggling from a lack of student numbers, hope to avoid.

This seeming lack of confidence in their entrance exams could be mitigated if the universities were more open to allowing outside parties to review and rate them. There are many language assessment organizations that (for a fee, of course) can scrutinize the exams, pointing out potential weaknesses and providing suggestions for improvement. Theoretically, the universities should then have stronger, more suitable tests, and should not be quite as reluctant about allowing the public to view them once the exam period is over.

Since Japanese universities generally do not wish to be seen as resisting suggestions from the Ministry of Education, most will probably comply with its request to make their exams public. However, since the wording of the directive is lacking much in the way of detail, there is room for interpretation about what can be considered "public." 
As such, one school of thought is that rather than post the exams on their websites, there is a strong possibility that many universities may instead keep a copy in their admissions office, making it available for viewing for those willing to visit the campus (Personal correspondence with Sapporo Medical University professor Shinji Kimura, 30 August 2018). In this way, the universities would also be able to avoid reimbursing those holding copyright over the previously published material appearing on the exams.

Another possible means of increased transparency would be for universities to send results of the exams to all applicants, regardless of whether they were accepted or rejected. Upon entry at some universities, it may be possible for first-year students to see their overall exam score and where they ranked among the other examinees. It is unlikely, however, that they are permitted to see their actual exam answers. Moreover, as described above, it is not common for universities to provide any exam information to unsuccessful applicants. Examinees have little recourse other than to trust that universities have been honest with the exam results. As the present scandal involving TMU and other universities indicates, that trust may be starting to waver.

Providing scores and rankings to all applicants would be helpful. Ideally, it would be beneficial if they could receive their scores for each question they answered on the exam. Universities could even provide applicants with a copy of their actual examination if so requested. In doing so, assuming that the universities follow through with the Ministry of Education's directive to make their exam problems and answers public, unsuccessful (and, of course, successful) applicants will have the opportunity to compare their answers to those considered to be officially correct. Knowing that applicants may have access to their individual exams could provide a strong deterrent to universities from manipulating scores in the manner conducted by TMU. However, for the same reason noted above about how universities may be reluctant to make their exam answers too public in that it would open them up to arguments over how problems with subjective answers are scored, at present the author believes it is unlikely that many universities will adopt this policy.

\section{Conclusion}

In response to an extremely embarrassing and public academic scandal involving a Japanese researcher in early 2014 (McNeill 2014), the Ministry of Education quickly issued a lengthy manual providing guidelines about how universities should respond to instances of academic misconduct (Ministry of Education, Culture, Sports, Science and Technology (MEXT) 2014). All universities are expected to provide information on research ethics to their faculty and graduate students. Additionally, results from conducted research must be preserved for a certain period of time and disclosed when deemed necessary.

These guidelines focus primarily on research misconduct. There is no mention of entrance exam score alterations. However, it is some measure of encouragement that the Ministry has acted quickly in response to past scandals and appears to be trying to do so with the present incident as well. Discouraging universities from having gender quotas would be an additional welcome step. At present, the Ministry will not name the other universities it suspects of discriminating against female applicants due to lack of conclusive evidence. If and when that evidence becomes clear, it is hoped that the 
Ministry will immediately announce which universities have been engaged in exam score manipulation.

It is of course too soon to know whether the Ministry's directive to universities to open up their exam material to the public will discourage policies such as those perpetrated by TMU. There is some comfort, however, to see that at least an effort is being taken to prevent similar scandals from occurring in the future. Moreover, in a very recent development, the Japan Accreditation Council for Medical Education has stripped the university of its international accreditation, meaning that it may now be impossible for graduates to acquire medical licenses in the United States (Nihon Keizai Shimbun 2018b). With all of these actions occurring, however, in the end, of course, it is up to the medical universities to live up to the standards they submit as their objectives, and take steps to ensure against a future repeat of the TMU scandal.

Abbreviation

TMU: Tokyo Medical University

\section{Acknowledgements}

The author wishes to express his gratitude to Professor Shinji Kimura for his thoughtful views about university attitudes toward publicizing their exams and providing several of the sources that were utilized in this study.

Funding

The author has received no funding for this manuscript.

Availability of data and materials

Data used in the present study is publically available, accessed from online sources. Interested parties should please refer to the references section for location details.

\section{Author's contribution}

GW is the sole author of this study and was responsible for the research and composition. The author read and approved the final manuscript.

\section{Competing interests}

The author declares that he has no competing interests.

\section{Publisher's Note}

Springer Nature remains neutral with regard to jurisdictional claims in published maps and institutional affiliations.

Received: 18 September 2018 Accepted: 30 November 2018

Published online: 27 December 2018

\section{References}

BBC News (2018) Tokyo Medical University apologises for changing female exam scores. https://www.bbc.com/news/worldasia-45108272. Accessed 20 Aug 2018

Copyright Research and Information Center (n.d.) Copyright law of Japan. Chapter II: rights of authors. http://www.cric.or.jp/ english/clj/cl2.html. Accessed 1 Sept 2018

Hokkaido University (2017) School of Medicine. https://www.global.hokudai.ac.jp/research-and-education/undergraduateschools/school-of-medicine/. Accessed 21 Aug 2018

Igakubu Juken Labo (n.d.) 2017 nendo gōkakusha/nyūgakusha no uchiwake danjōhi rankingu [2017 acceptance/enrollment rates at private medical universities classified by gender]. https://www.igakubujuken.jp/ranking/gender?year=2017. Accessed 22 Aug 2018

Igakubu Juken Manual (n.d.) Hensachi rankingu [Hensachi rankings]. https://www.med-pass.net/rank/hensachi/. Accessed 22 Aug 2018

Japan Today (2018) Tokyo Medical Univ to accept some applicants denied by exam rigging. https://japantoday.com/ category/national/tokyo-medical-univ.-to-accept-some-applicants-denied-by-exam-rigging. Accessed 7 Nov 2018

Kawaii Juku Ishin Juku (2018a) Kokuritsu daigaku igakubu hensachi ichiran [Hensachi of medical departments at public universities]. http://ishin.kawai-juku.ac.jp/exam/deviation/. Accessed 22 Aug 2018

Kawaii Juku Ishin Juku (2018b) Shiritsu daigaku igakubu hensachi ichiran [Hensachi of medical departments at private universities]. http://ishin.kawai-juku.ac.jp/exam/deviation/deviation2.php. Accessed 22 Aug 2018

Kyodo News (2018) More Japanese medical schools disadvantaged female applicants: minister. https://english.kyodonews.net/ news/2018/10/d1251b53afb3-more-medical-schools-disadvantaged-female-applicants-minister.html. Accessed 6 Nov 2018

Kyoto University (n.d.) Ideals and objectives in the Faculty of Medicine. http://www.med.kyoto-u.ac.jp/en/faculty/f-policy/ ideals_objectives/. Accessed 21 Aug 2018

Livedoor News (2018) Tōkyō ikadai ha gakuhi ōhabagen "shidai igakubu" sotsugyō made no sōgaku ha [Tokyo Medical University private medical department to make large reduction to student fees]. http://news.livedoor.com/article/detail/ 15529934/. Accessed 8 Nov 2018 
Makino M (2016) Times Higher Education rankings and hensachi in Japanese universities. Mark: My Words. https:/ffuturealisreal. wordpress.com/2016/10/09/times-higher-education-rankings-and-hensachi-in-japanese-universities/. Accessed 22 Aug 2018

McCurry J (2018) 'Betrayed': victims of Tokyo medical school scandal speak out. The Guardian. https:/www.theguardian.com/ world/2018/aug/10/betrayed-victims-of-tokyos-medical-school-scandal-react. Accessed 20 Aug 2018

McNeill D (2014) Academic scandal shakes Japan. The New York Times. https://www.nytimes.com/2014/07/07/world/asia/ academic-scandal-shakes-japan.html. Accessed 10 Sept 2018

Medical Labo (n.d.) Gakuhi [Educational fees]. https://www.medical-labo.com/entrance/fee.html. Accessed 25 Aug 2018

Medic Tomas (2017) Jugyōryō no annai [Guide to tuition fees]. https://www.tomas.co.jp/medic/price/. Accessed 25 Aug 2018.

Ministry of Education, Culture, Sports, Science and Technology (MEXT) (2014). Guidelines for responding to misconduct in research. http://www.mext.go.jp/a_menu/jinzai/fusei/_icsFiles/afieldfile/2015/07/13/1359618_01.pdf. Accessed 11 Sept 2018

Ministry of Education, Culture, Sports, Science and Technology (MEXT) (2018) Heisei 31 nendo daigaku nyūgakusha senbatsu jisshi yōkō ni tsuite (tsūchi) [Notification of implementation guidelines concerning the system for selecting 2019 university entrants]. http://www.mext.go.jp/component/a_menu/education/detail/_icsFiles/afieldfile/2018/06/07/ 1282953_02_1.pdf. Accessed 30 Aug 2018

Murakoshi K, Sano A (2018) Tokyo medical school takes heat for gender discrimination. Nikkei Asian Review. https://asia. nikkei.com/Politics/Tokyo-medical-school-takes-heat-for-gender-discrimination. Accessed 20 Aug 2018

New's Vision (2018) Tōkyō idai dakejanai daigaku juken no seisabetsu. "Mensetsu ya seibutsu no haiten de chōsei kanō" no shidai igakubu, "joshi yūgū" no Tōdai suisen nyūshi mo [Gender discrimination on exams not limited to Tokyo Medical University. Adjustments to interview and biology scores at medical departments at private schools and preferential treatment toward women on Tokyo University's recommendation entrance exams]. https://news-vision.jp/article/188702/. Accessed 23 Aug 2018

NHK World - Japan (2018) Exam fixing: 65\% of female doctors 'understand.'

Nikkan Sports (2018) Tökyō ikadai, joshi dake denaku 3ro ijō danshi mo gökaku yokusei [Not just female examinees, Tokyo Medical University also suppressed men taking exam who had taken the exam more than three times previously]. https:/www.nikkansports.com/general/news/201808070000015.html. Accessed 20 Aug 2018

Nogi K (2018) Women demand Tokyo Medical University compensate them over entry test rigging. Japan Today. https:// japantoday.com/category/national/Women-demand-Tokyo-Medical-University-compensate-them-over-entry-test-rigging. Accessed 25 Oct 2018

Organization for Economic Cooperation and Development (OECD) (2018) Data: Doctors. https://data.oecd.org/healthres/ doctors.htm. Accessed 3 Sept 2018

Sankei News (2018) Shōwa daii mo fusei. Tokuten sōsa ha [jōshiki] nanoka [Showa medical school also dishonest. Score manipulation is "common sense"?] https:/www.sankei.com/column/news/181017/dm1810170002-n1.html. Accessed 16 Nov 2018

Sapporo Medical University (n.d.) About Sapporo Medical University - code of conduct. http://web.sapmed.ac.jp/e/about/index.html

Asahi Shimbun (2018a) Tōkyō idai, 11 nen kara joshi jukensha wo ōhabagenten gōkakuritsu gekigen [Tokyo Medical University lowered female examinees scores since 2011, drastically reducing acceptance rates]. https:/www.asahi.com/ articles/ASL8254KNL82UTIL02G.html?iref=pc_Ss_date. Accessed 22 Aug 2018

Asahi Shimbun (2018b) Ishi 65\% "joshi genten rikai dekiru" jinzai kaisha netto chōsa [Recruitment agency survey: 65\% of doctors can understand score reduction]. https://www.asahi.com/articles/ASL884F1XL88UTIL017.html. Accessed 24 Aug 2018

Asahi Shimbun (2018c) Sapporo ikadai de shutsudai misu, hitori wo tsuika gōkaku [Mistake on Sapporo Medical University entrance exam, additional applicant passes]. http://www.asahi.com/articles/ASL3X3VLFL3XUBQU003.html. Accessed 28 Aug 2018

Mainichi Shimbun (2018) Nyūshi: Juntendōdai igakubu demo joshi sabetsu [Discrimination against women also in Juntendo medical department's entrance exam]. https:/mainichi.jp/articles/20181023/k00/00m/040/162000c. Accessed 16 Nov 2018

Nihon Keizai Shimbun (2018a) Tōkyō idai, joshi jukensha wo ichiritsu genten danjosū wo sōsa ka [Tokyo medical school across the board deduction of female examinees' scores: management of male and female acceptance numbers?]. https://www.nikkei.com/article/DGXMZO3370137002082018CC0000/. Accessed 22 Aug 2018

Nihon Keizai Shimbun (2018b) Tōkyō idai no kokusai nintei torikeshi hyōka kikō, nyūshi fusei de [Tokyo Medical University's international accreditation cancelled by Council due to entrance exam misconduct]. https://www.nikkei.com/article/ DGXMZO38115490S8A121C1CC1000/. Accessed 27 Nov 2018

Takahashi K, Nin T, Akano M, Hasuike Y, lijima H, Suzuki K (2017) Views of Japanese medical students on the work-life balance of female physicians. Int J Med Educ 8:165-169. https://doi.org/10.5116/ijme.5907.0d44

Tanaka S, Izutani Y (2018) Tōkyō idai no tensū sōsa "mohaya josei sabetsu igai no nanimono demo nai" to shiteki. Naibu chōsai ga kaiken [Internal investigation internal committee press conference: Tokyo Medical University score reduction "cannot be considered anything other than discrimination against women"]. Huffpost Japan. https://www.huffingtonpost. jp/2018/08/07/tokyo-medical-university_a_23497229/. Accessed 20 Aug 2018

Tanaka S, Kinkozan M (2018) Tōkyō idai dake janai? Nyūshi de no danjo sabetsu. Ishira ga shōgen "idai zentai ni aru to makoto shiyaka ni uwasasareteita" [Not just Tokyo medical university? Entrance examination gender discrimination. Doctors claim there are plausible rumors it occurs at all medical universities]. Huffpost Japan. https://www. huffingtonpost.jp/2018/08/01/toukyouika-joseisabetu_a_23494326/. Accessed 20 Aug 2018

The Japan Times (2018a) Tokyo Medical University discriminated against female applicants by lowering entrance exam scores: sources. https://www.japantimes.co.jp/news/2018/08/02/national/tokyo-medical-university-discriminated-femaleapplicants-lowering-entrance-exam-scores-sources/\#.W4eW4pP7TJw. Accessed 20 Aug 2018

The Japan Times (2018b) Kyoto University to accept 17 felled by flawed entrance test. https://www.japantimes.co.jp/news/ 2018/02/01/national/kyoto-university-admit-17-erroneously-rejected-applicants/\#.XByJXC_7Q3h. Accessed 22 Aug 2018

The Mainichi (2018) Tokyo Medical Univ. Substantially padded scores of 'priority' entrance exam applicants. https://mainichi. jp/english/articles/20180806/p2a/00m/Ona/003000c. Accessed 22 Aug 2018

Tokyo Medical University (n.d.a) Policy statements. http:/www.tokyo-med.ac.jp/english/admission/med/policy.html. Accessed 21 Aug 2018

Tokyo Medical University (n.d.b) Igakuka ippan nyūshi [Department of Medicine general entrance examination]. http://www. tokyo-med.ac.jp/med/exam.html. Accessed 20 Aug 2018 
Tokyo Medical University (n.d.c) Tōkyō ika daigaku heisei 30 nendo nyūgakusha senbatsu jōkyō [Status of Tokyo Medical University 2018 student entrants]. http://www.tokyo-med.ac.jp/med/media/docs/med-data.pdf. Accessed 20 Aug 2018

Tokyo Medical University (n.d.d) Igakuka gakusei nōfukin [Department of Medicine student fees]. http://www.tokyo-med.ac.jp/ med/payment.html. Accessed 20 Aug 2018

Tokyo Shimbun (2018) Joshi genten, gōkakuritsu osaeru Tōkyō idai nyūshi takai rishokuritsu riyū [Citing a high [female] turnover rate in the medical field, Tokyo Medical University reduces women's scores, suppressing acceptance rate]. http://www.tokyo-np.co.jp/article/national/list/201808/CK2018080302000147.html. Accessed 20 Aug 2018

World Economic Forum (2017) The global gender gap report 2017. http://www3.weforum.org/docs/WEF_GGGR_2017.pdf. Accessed 28 Aug 2018

Ready to submit your research? Choose BMC and benefit from:

- fast, convenient online submission

- thorough peer review by experienced researchers in your field

- rapid publication on acceptance

- support for research data, including large and complex data types

- gold Open Access which fosters wider collaboration and increased citations

- maximum visibility for your research: over $100 \mathrm{M}$ website views per year

At $\mathrm{BMC}$, research is always in progress.

Learn more biomedcentral.com/submissions 